\title{
Temporal Evolution of Air Pollution Levels in the Wider Industrial Zone of Kavala, East Macedonia and Thrace, Greece
}

\author{
Gaidajis Georgios
}

Laboratory of Environmental Management and Industrial Ecology (LEMIE), Department of Production and Management Engineering, Democritus University of Thrace, 67100, Xanthi, Greece

Received 15 September 2018; Accepted 9 March 2019

\begin{abstract}
The aim of the present research is to examine the temporal evolution of air pollution levels in the wider industrial zone of Kavala region, Northeastern Greece in terms of four major air pollutants: sulfur dioxide $\left(\mathrm{SO}_{2}\right)$, hydrogen sulfide $\left(\mathrm{H}_{2} \mathrm{~S}\right)$, methane $\left(\mathrm{CH}_{4}\right)$ and total hydrocarbons (THC). The daily average concentrations of the specific pollutants were recorded for the period 2004-2016 (13 years), in parallel with key meteorological data. Results indicated a slightly increasing trend of concentrations over the years and especially during the period 2010-2013. In all cases the concentrations were below the limits set by the national legislation and alarm values. High values of the ratios average $\mathrm{SO} 2$ and $\mathrm{H} 2 \mathrm{~S}$ concentrations to median $\mathrm{SO} 2$ and $\mathrm{H} 2 \mathrm{~S}$ concentrations indicated few episodes with high concentration levels of $\mathrm{SO}_{2}$ and $\mathrm{H}_{2} \mathrm{~S}$. The concentration levels measured during warm and cold period and during weekdays and weekends were identical indicating uniform sources within the year.
\end{abstract}

Keywords: Air quality, industrial area, sulfur compounds, hydrocarbons.

\section{Introduction}

Air pollution deriving from industrial activities is a major concern worldwide. Intense industrialization can lead to the degradation of the ambient air quality, thus affecting both workers and people living within adjacent residential areas. External costs associated to atmospheric pollution from industrial activities (e.g. due to climate mitigation and human mortality) can be significantly high and should be taken into account during decision making ${ }^{[1]}$. Several studies have been conducted around the world that investigate the air quality in industrial areas in terms of various pollutants such as volatile organic compounds ${ }^{[2]}$, trace elements ${ }^{[3]}$, air pollution indices (including $\mathrm{SO}_{2}, \mathrm{NO}_{2}$, $\left.\mathrm{PM}_{10}\right)^{[4]}$ and others. Some of these studies have attempted to predict future air pollution levels through detailed monitoring ${ }^{[5]}$.

Despite the recent efforts in EU, still a large part of European population is exposed to poor air quality ${ }^{[6,7]}$. The aim of the specific paper is to evaluate the temporal evolution of air pollution levels in the wider industrial zone of Kavala region, Northeastern Greece. Residential areas are located in close proximity to the industrial zone whereas the wider area is characterized by its rich natural environment neighboring with the National Park of East Macedonia and Thrace. In that aspect, the monitoring of air quality in the examined location is significant since it affects both human health and natural environment.

*E-mail address: geogai@pme.duth.gr ISSN: $1791-2377$ @ 2018 Eastern Macedonia and Thrace Institute of Technology. All rights reserved. doi:10.25103/jestr.121.06

\section{Materials and Methods}

\section{Description of Sampling Area}

The sampling station was located within the boundaries of the wider industrial zone of Kavala situated in the region of Eastern Macedonia and Thrace, Northeastern Greece. The climate of the specific area is Csa sub-type under the Köppen climate classification ${ }^{[8]}$ reference which indicates mild temperate climate with hot dry-summers. Data were acquired from an environmental monitoring station $\left(40^{\circ} 58^{\prime} 01.03^{\prime \prime} \mathrm{N}, 24^{\circ} 32^{\prime} 45.95^{\prime} \mathrm{E}\right)$ which is positioned in close proximity $(<5 \mathrm{~km})$ with key industrial (oil desulfurization plant, fertilizer and chemical plant, smaller manufacturing plants) and emission intensive anthropogenic activities (commercial port, airport, national highway) (Figure 1). Around the industrial zone, there are several residential areas most significant of which is the town of Kavala $(\approx 55,000$ residents), located $12 \mathrm{~km}$ west of the sampling station.

\section{Description of Sampling Profile-Equipment}

The sampling campaign was conducted during the period 2004 to 2016 (13 years). Data utilized in this study, were acquired from the environmental monitoring station of Kavala Oil S.A. as previously mentioned. The sampling equipment was installed into an air-conditioned container that kept the temperature between 15 and $25{ }^{\circ} \mathrm{C}$. Four major air pollutants were simultaneously recorded (in average daily concentrations; $\mathrm{N}=4,749$ recordings per parameter): sulfur dioxide $\left(\mathrm{SO}_{2}\right)$, hydrogen sulfide $\left(\mathrm{H}_{2} \mathrm{~S}\right)$, methane $\left(\mathrm{CH}_{4}\right)$ and total hydrocarbons (THC).

$\mathrm{SO}_{2}$ results from the burning of sulfur or materials containing sulfur and can affect both human health by harming the respiratory system and the environment ${ }^{[9]} \cdot \mathrm{H}_{2} \mathrm{~S}$ is a highly hazardous and toxic gas with characteristic odor that can cause various health effects depending on the route, 
length and intensity of exposure. Gas operations and petroleum refining are the main non-natural sources of hydrogen sulfide ${ }^{[10]} . \mathrm{CH}_{4}$ has both anthropogenic and natural sources, is a major greenhouse gas and can contribute to the photochemistry of the atmosphere. THC refers to the measurement of chemicals containing carbon and hydrogen atoms (incl. $\mathrm{CH}_{4}$ ) and their environmental and health effects vary depending on specific hydrocarbon concentrations.

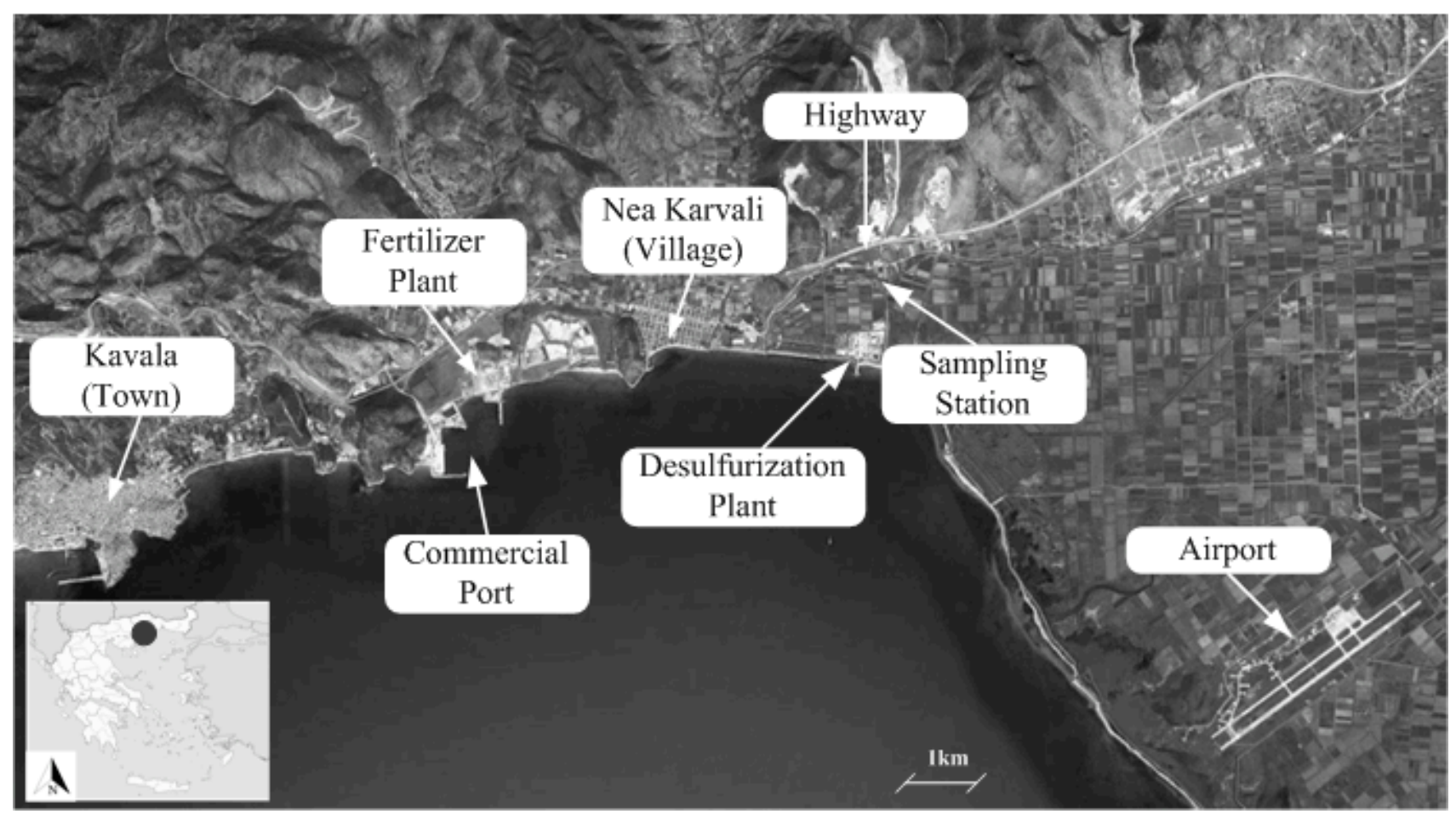

Fig. 1. Sampling station and emission intensive areas.

The specific pollutants are monitored following specific environmental terms in order to monitor and assess the adjacent industrial processes of the desulfurization plant and their respective impact on the atmospheric quality. A UV fluorescent $\mathrm{SO}_{2}$ analyzer (Model $\mathrm{AF} 22 \mathrm{M}$ ) and a flame ionization hydrocarbon analyzer (Model HC51M) were utilized for measuring $\mathrm{SO}_{2}-\mathrm{H}_{2} \mathrm{~S}$ and THC $-\mathrm{CH}_{4}$ respectively. The sampling inlet was installed 3 meters above the ground surface. Weather data (temperature, humidity, wind speed and direction) were additionally recorded with the application of meteorological instruments.

\section{Predominant Weather Condition}

Measurements during the 13 year sampling campaign indicated that the predominant wind direction was southsouthwest $(\mathrm{SSW}=13.4 \%)$. The presence of south winds (Figure 2) increases the possibility that industrial emissions are recorded since the industrial facilities are south of the sampling station. The wind speed ranged from $0.1-16.8 \mathrm{~m} / \mathrm{s}$ whereas moderate winds $(>6 \mathrm{~m} / \mathrm{s})$ were often recorded $(16.3 \%)$. Wind speeds in between the range of $3-5 \mathrm{~m} / \mathrm{s}$ were recorded at a percentage of $45 \%$. The impact of winds in the examined area is twofold as they have both the ability to dissolve gaseous emissions but on the other hand can simultaneously transfer them in nearby towns and villages.

The range of average daily temperature was -3 to $34{ }^{0} \mathrm{C}$ whereas the average annual temperature for the sampling period was $16-18{ }^{\circ} \mathrm{C}$ exhibiting an increasing trend over the years. In Figure 3, the monthly average values per weather parameter for the 13 - year period are presented exhibiting a typical Mediterranean profile. During the summer higher percentage of winds are from the southwest while in parallel the wind speed is decreasing. The average annual humidity ranged from $59 \%$ (2009) to $70 \%$ (2005) whereas the months with the highest and lowest humidity were February (68\%) and August (59\%) respectively.

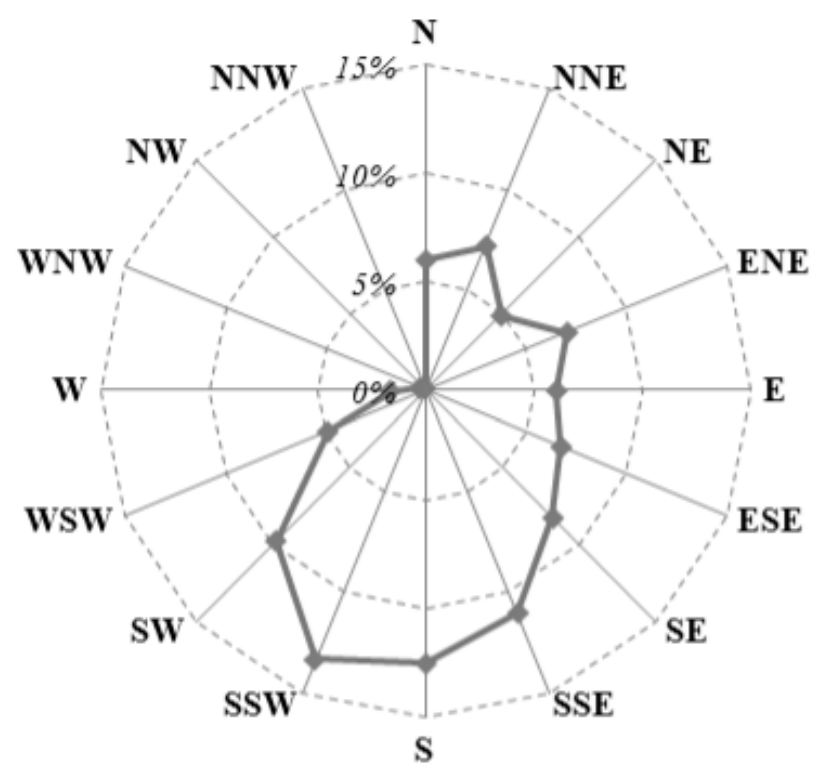

Fig. 2. Wind rose diagram for the sampling period.

The annual concentration levels per pollutant measured during the sampling campaign are summarized in Table 1 . The range of average concentrations for THC (0.8-1.8 $\left.\mathrm{mg} / \mathrm{m}^{3}\right)$ and $\mathrm{CH}_{4}\left(0.7-1.6 \mathrm{mg} / \mathrm{m}^{3}\right)$ is slightly increasing throughout the years. Comparing the average to median values (Table 1), they were found to be close to unity for 
THC and $\mathrm{CH}_{4}$. Ratios close to unity indicate a smooth distribution between high and low values, an indication that consistent sources, sinks and characteristics prevail in general in the area. On the other hand ratios significantly higher (or lower) than unity, indicate data sets biased from sporadic data sets of relatively high (or low) concentrations. That was the case mainly for $\mathrm{SO}_{2}$ and secondly $\mathrm{H}_{2} \mathrm{~S}$ where the ratios were in the range of $1.0-7.5$ and 1.0-3.4 respectively. Those higher values especially for years 2014 and 2015 indicate few episodes of high level concentrations of $\mathrm{SO}_{2}$ and $\mathrm{H}_{2} \mathrm{~S}$. It should be noticed here that $\mathrm{THC}$ and $\mathrm{CH}_{4}$ did not exhibit similar behavior, suggesting that they may originate from different emission regime.

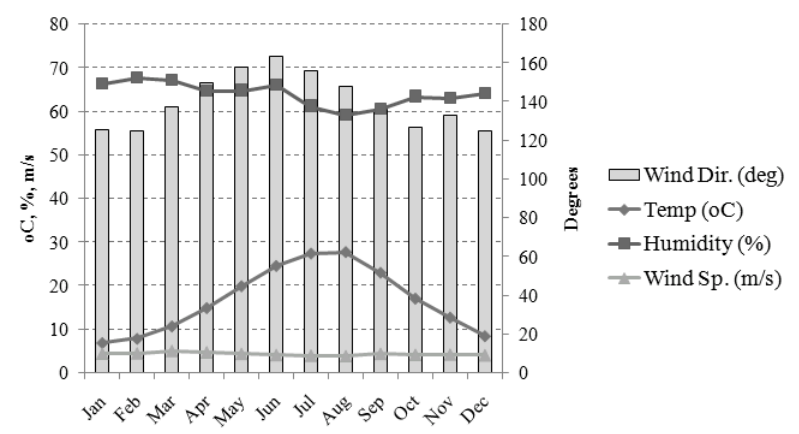

Fig. 3. Monthly average values of key weather parameters during the sampling campaign.

\section{Results and Discussion}

\section{Temporal Evolution}

concentrations of $\mathrm{SO}_{2}\left(3.7-14.0 \mu \mathrm{g} / \mathrm{m}^{3}\right)$ and $\mathrm{H}_{2} \mathrm{~S}(0.2-8.8$ $\mu \mathrm{g} / \mathrm{m}^{3}$ ), especially during $2010-2013$ when a noticeable rise of the concentrations is recorded (Figure 4). The standard deviation for $\mathrm{SO}_{2}$ and $\mathrm{H}_{2} \mathrm{~S}$ ranged from 2.0-13.0 and 0.2-8.8 $\mu \mathrm{g} / \mathrm{m}^{3}$ respectively. $\mathrm{SO}_{2}$ derives from fuel combustion and industrial activities such as oil refining and sulfate treatment. In the study area, the presence of such activities is intense. Additionally, two highways are placed close to the sampling station, satisfying both local and international transportation needs that further hinder the air quality of the examined region. The recorded $\mathrm{SO}_{2}$ concentrations, were significantly lower compared to urban centers even in non-heating periods such as large Chinese cities $\left(5-40 \mu \mathrm{g} / \mathrm{m}^{3}\right)^{[11]}$, or Tehran $\left.\left(110-150 \mu \mathrm{g} / \mathrm{m}^{3}\right)^{[12}\right]$ but were comparable to suburban site in Greece however with significant traffic load (Rio-Antirio, 1.5-3.0 $\left.\mu \mathrm{g} / \mathrm{m}^{3}\right)^{[13]}$ or even to suburnan sites of $\mathrm{US}^{[14]}$.

Around the premises of the industrial zone there are marshy areas where due to the anaerobic bacteria degradation of organic substances containing sulfur, are potential sources of $\mathrm{H}_{2} \mathrm{~S}$. Consequently, within the boundaries of the examined region, there is a significant presence of both physical processes and anthropogenic activities that can highly affect the concentration levels of $\mathrm{SO}_{2}$ and $\mathrm{H}_{2} \mathrm{~S}$.

Table 1. Annual evolution of concentration levels during the period 2004-2016.

\begin{tabular}{|c|c|c|c|c|c|c|c|c|c|c|c|c|c|c|}
\hline \multicolumn{2}{|c|}{ Year } & 2004 & 2005 & 2006 & 2007 & 2008 & 2009 & 2010 & 2011 & 2012 & 2013 & 2014 & 2015 & 2016 \\
\hline \multirow{6}{*}{$\begin{array}{l}\mathrm{SO}_{2} \\
\mu \mathrm{g} / \mathrm{m}^{3}\end{array}$} & Avg. & 3.7 & 3.9 & 4.5 & 6.1 & 4.0 & 4.2 & 14.0 & 7.7 & 11.2 & 10.1 & 4.2 & 4.4 & 6.5 \\
\hline & Median & 1.7 & 1.9 & 2.7 & 3.7 & 3.9 & 4.1 & 11.2 & 5.3 & 8.4 & 4.2 & 0.6 & 0.6 & 3.6 \\
\hline & Avg./Med & 2.1 & 2.0 & 1.7 & 1.7 & 1.0 & 1.0 & 1.3 & 1.4 & 1.3 & 2.4 & 7.3 & 7.5 & 1.8 \\
\hline & SD & 5.6 & 5.4 & 5.5 & 6.8 & 4.2 & 2.0 & 13.0 & 8.5 & 11.7 & 14.2 & 7.7 & 6.9 & 9.0 \\
\hline & Min & $<0.1$ & $<0.1$ & $<0.1$ & $<0.1$ & $<0.1$ & 0.1 & $<0.1$ & $<0.1$ & $<0.1$ & $<0.1$ & $<0.1$ & $<0.1$ & $<0.1$ \\
\hline & Max & 48.8 & 29.1 & 54.0 & 46.3 & 44.2 & 15.4 & 80.6 & 51.7 & 80.6 & 85.9 & 60.4 & 28.0 & 57.3 \\
\hline \multirow{6}{*}{$\begin{array}{l}\mathrm{H}_{2} \mathrm{~S} \\
\mu \mathrm{g} / \mathrm{m}^{3}\end{array}$} & Avg. & 0.4 & 0.4 & 0.2 & 0.4 & 1.5 & 1.6 & 7.3 & 6.0 & 8.8 & 6.4 & 3.5 & 4.9 & 3.3 \\
\hline & Median & 0.3 & 0.4 & 0.2 & 0.3 & 1.4 & 1.5 & 6.5 & 3.8 & 5.5 & 3.9 & 1.9 & 1.4 & 1.2 \\
\hline & Avg./Med & 1.4 & 1.2 & 1.4 & 1.2 & 1.1 & 1.0 & 1.1 & 1.6 & 1.6 & 1.7 & 1.8 & 3.4 & 2.8 \\
\hline & SD & 0.4 & 0.3 & 0.2 & 0.3 & 1.1 & 0.7 & 5.6 & 6.6 & 8.8 & 7.1 & 3.9 & 6.7 & 4.7 \\
\hline & Min & $<0.1$ & $<0.1$ & $<0.1$ & $<0.1$ & $<0.1$ & 0.1 & $<0.1$ & $<0.1$ & $<0.1$ & $<0.1$ & $<0.1$ & $<0.1$ & $<0.1$ \\
\hline & Max & 2.8 & 1.6 & 0.9 & 1.7 & 4.9 & 3.4 & 25.4 & 31.0 & 35.5 & 35.3 & 14.9 & 28.7 & 21.3 \\
\hline \multirow{6}{*}{$\begin{array}{l}\mathrm{CH}_{4} \\
\mathrm{mg} / \mathrm{m}^{3}\end{array}$} & Avg. & 0.7 & 1.1 & 1.1 & 1.1 & 1.4 & 1.3 & 1.0 & 1.0 & 1.6 & 1.6 & 1.4 & 1.5 & 1.6 \\
\hline & Median & 0.7 & 1.1 & 1.1 & 1.1 & 1.5 & 1.3 & 1.0 & 0.9 & 1.6 & 1.6 & 1.3 & 1.4 & 1.5 \\
\hline & Avg./Med & 0.9 & 1.0 & 1.0 & 1.0 & 0.9 & 1.0 & 1.0 & 1.1 & 1.0 & 1.0 & 1.1 & 1.0 & 1.0 \\
\hline & SD & 0.5 & 0.1 & 0.3 & 0.2 & 0.3 & 0.2 & 0.2 & 0.4 & 0.2 & 0.3 & 0.3 & 0.3 & 0.4 \\
\hline & Min & $<0.1$ & 0.5 & 0.3 & 0.7 & 0.8 & 0.9 & 0.6 & 0.5 & 0.5 & 0.5 & 0.9 & 1.0 & 0.7 \\
\hline & Max & 1.5 & 1.5 & 1.9 & 1.7 & 1.9 & 1.9 & 1.4 & 2.2 & 2.0 & 2.3 & 2.3 & 2.2 & 2.5 \\
\hline \multirow{6}{*}{$\begin{array}{l}\text { THC } \\
\mathrm{mg} / \mathrm{m}^{3}\end{array}$} & Avg. & 0.8 & 1.2 & 1.6 & 1.1 & 1.5 & 1.5 & 1.3 & 1.4 & 1.8 & 1.8 & 1.6 & 1.6 & 1.7 \\
\hline & Median & 0.8 & 1.2 & 1.7 & 1.0 & 1.7 & 1.5 & 1.3 & 1.3 & 1.8 & 1.8 & 1.5 & 1.6 & 1.7 \\
\hline & Avg./Med & 1.0 & 1.0 & 1.0 & 1.0 & 0.9 & 1.0 & 1.0 & 1.1 & 1.0 & 1.0 & 1.1 & 1.0 & 1.1 \\
\hline & SD & 0.5 & 0.1 & 0.5 & 0.4 & 0.4 & 0.2 & 0.2 & 0.4 & 0.2 & 0.3 & 0.3 & 0.3 & 0.4 \\
\hline & Min & $<0.1$ & 0.5 & 0.6 & 0.3 & 0.3 & 1.1 & 0.3 & 0.7 & 0.7 & 0.7 & 1.1 & 1.1 & 1.0 \\
\hline & Max & 1.7 & 1.6 & 2.6 & 2.4 & 2.1 & 2.0 & 1.9 & 2.5 & 2.6 & 2.4 & 2.5 & 2.5 & 2.7 \\
\hline
\end{tabular}

Significant variations are observed regarding

In order to better examine the temporal evolution of air pollution levels and compare them with respective limits (national legislation and alarm values set by industry), the average daily concentrations for the period 2004-2016 are presented (Figures 5 and 6). An increasing trend for all four pollutants is observed throughout the years, especially for
$\mathrm{H}_{2} \mathrm{~S}$, indicating the need to continue monitoring and to pursue source apportionment for the specific pollutants. However, in all cases the average daily concentrations are well below the $24 \mathrm{~h}$ limits set by legislation and alarm values $\left(\mathrm{SO}_{2}: 125 \mu \mathrm{g} / \mathrm{m}^{3}, \mathrm{H}_{2} \mathrm{~S}: 15 \mathrm{mg} / \mathrm{m}^{3}\right.$, THC: $5 \mathrm{mg} / \mathrm{m}^{3}, \mathrm{CH}_{4}: 5$ $\mathrm{mg} / \mathrm{m}^{3}$ ). The maximum daily $\mathrm{SO}_{2}$ and $\mathrm{H}_{2} \mathrm{~S}$ concentrations 
recorded were 86 and $36 \mu \mathrm{g} / \mathrm{m}^{3}$ respectively, still below the legislated limit.

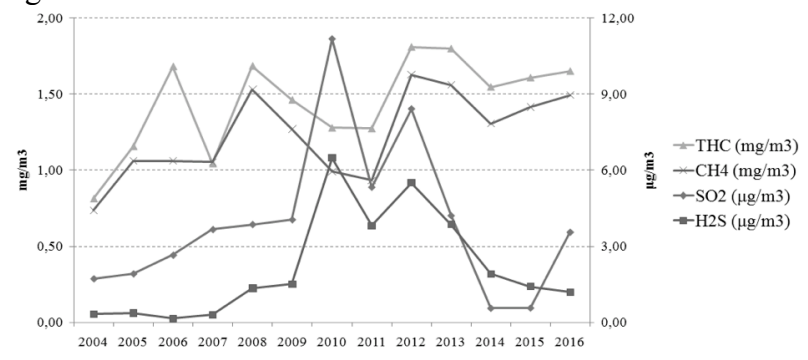

Fig. 4. Evolution of median concentration levels of pollutants.
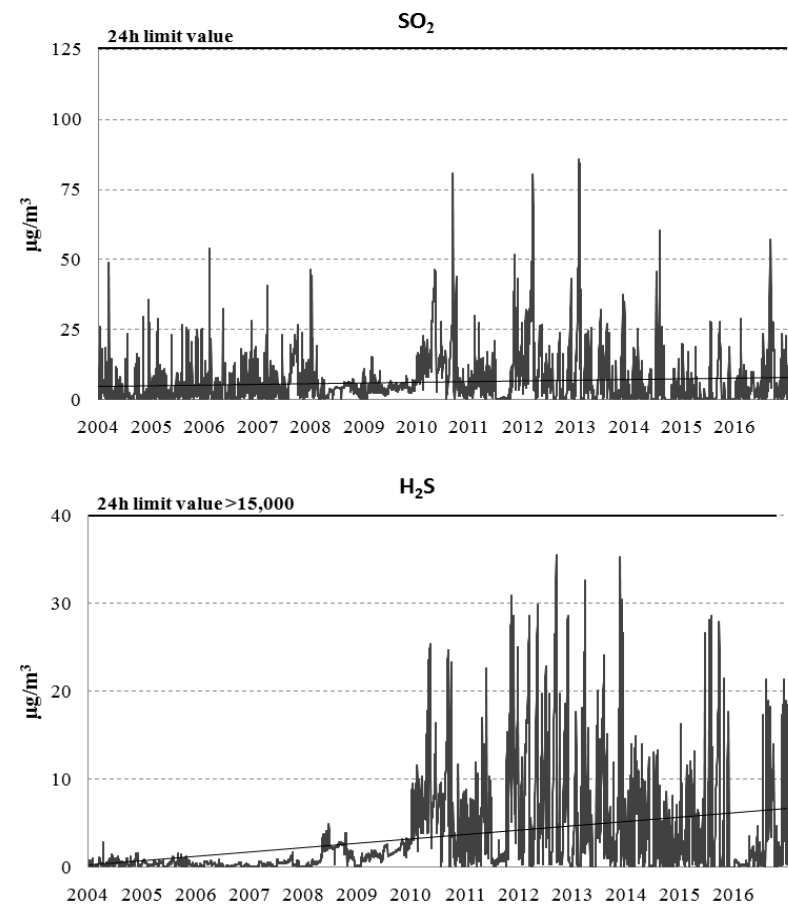

Fig. 5. Temporal variation of daily concentration levels of $\mathrm{SO}_{2}$ and $\mathrm{H}_{2} \mathrm{~S}$.
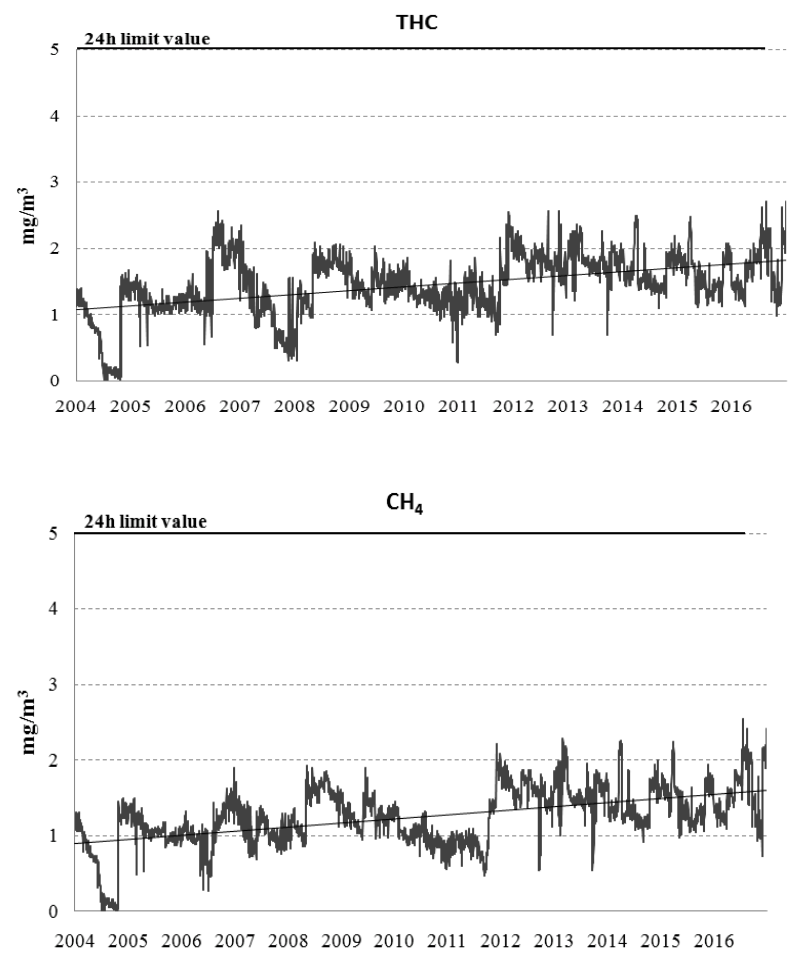

Fig. 6. Temporal variation of daily concentration levels of THC and $\mathrm{CH}_{4}$

\section{Seasonal Variation}

In an attempt to assess whether seasonal factors may potentially affect the concentration levels of the examined pollutants, the monthly average concentration levels per pollutant and the daily average concentrations on weekdays and weekends were extracted (Table 2). The monthly average concentration levels of $\mathrm{SO}_{2}$ during the cold period $\left(1 / 10-31 / 3\right.$; avg. temperature $\left.=10.7{ }^{\circ} \mathrm{C}\right)$ were slightly higher $\left(6.8 \mu \mathrm{g} / \mathrm{m}^{3}\right)$ in comparison with warm months (1/4-30/9; avg. temperature $\left.=23.0^{\circ} \mathrm{C}\right)\left(6.3 \mu \mathrm{g} / \mathrm{m}^{3}\right)$. Seasonality affects $\mathrm{SO}_{2}$ and $\mathrm{H}_{2} \mathrm{~S}$ in opposite ways, since concentrations levels of $\mathrm{H}_{2} \mathrm{~S}$ were higher during warm period (3.7 and $3.2 \mu \mathrm{g} / \mathrm{m}^{3}$ for warm and cold period respectively), indicating the temporal persistence of different characteristics (e.g. sources, sinks) within the year.

Table 2. Seasonal variation of concentrations between coldwarm period and weekdays-weekends.

\begin{tabular}{|c|c|c|c|c|}
\hline & $\begin{array}{c}\text { Oct - Mar } \\
\text { (Cold } \\
\text { Period) } \\
\end{array}$ & $\begin{array}{l}\text { Apr - Sep } \\
\text { (Warm } \\
\text { Period) }\end{array}$ & $\begin{array}{c}\text { Weekda } \\
\text { ys }\end{array}$ & $\begin{array}{c}\text { Weeken } \\
\text { ds }\end{array}$ \\
\hline $\mathrm{SO}_{2}\left(\mu \mathrm{g} / \mathrm{m}^{3}\right)$ & 6.8 & 6.3 & 6.5 & 6.5 \\
\hline $\mathrm{H}_{2} \mathrm{~S}\left(\mu \mathrm{g} / \mathrm{m}^{3}\right)$ & 3.2 & 3.7 & 3.4 & 3.5 \\
\hline & 1.5 & 1.4 & 1.4 & 1.4 \\
\hline$\left(\mathbf{m g} / \mathbf{m}^{3}\right)$ & 1.3 & 1.2 & 1.3 & 1.3 \\
\hline Temp $\left({ }^{\circ} \mathrm{C}\right)$ & 10.7 & 23.0 & 16.9 & 16.8 \\
\hline $\begin{array}{c}\text { Humidity } \\
\text { (\%) }\end{array}$ & 65.3 & 62.8 & 64.1 & 63.9 \\
\hline
\end{tabular}

During September a noticeable peak in $\mathrm{SO}_{2}$ concentrations is observed (Figure 7) especially during the years 2007, 2010 and 2016 when the average monthly concentrations were above $15 \mu \mathrm{g} / \mathrm{m}^{3}$. The specific finding indicates potential increased activity in the wider industrial zone during September (usually start-up after maintenance) that may burden the air quality of the area and need to be further examined. For THC and $\mathrm{CH}_{4}$ concentration levels were similar during both periods $\left(1.5\right.$ and $1.4 \mathrm{mg} / \mathrm{m}^{3}$ for THC and 1.3 and $1.2 \mathrm{mg} / \mathrm{m}^{3}$ for $\mathrm{CH}_{4}$ for cold and warm period respectively) indicating uniform relative characteristics in the wider area. Additionally, the average concentrations for all four pollutants during weekdays and weekends were identical. Considering the above, no safe results can be extracted regarding the contribution of nonindustrial anthropogenic activities related to seasonality (e.g. heating and transportation needs).

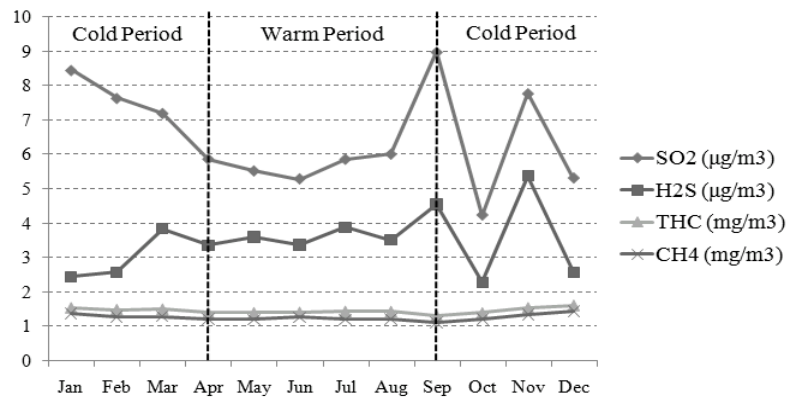

Fig. 7. Monthly average values of pollutants for the 13-year reported period.

With a view to efficiently examine potential relationships among pollutants monitored, correlation analysis was implemented. Results indicated that $\mathrm{THC}$ and $\mathrm{CH}_{4}$ present a very high correlation $(\mathrm{R}=0.858$, number of entries $\mathrm{n}=$ 
$4,749)$ whereas a noticeable but lower correlation between $\mathrm{SO}_{2}$ and $\mathrm{H}_{2} \mathrm{~S}$ was also observed $(\mathrm{R}=0.670, \mathrm{n}=4,749)$. On the contrary, not any significant correlation $(\mathrm{R}<0.200)$ among the four air pollutants and weather parameters was identified.

\section{Conclusions}

The aim of the specific paper was to assess the temporal evolution (2004-2016) of air pollution levels in the wider industrial zone of Kavala region, Northeastern Greece in terms of sulfur dioxide $\left(\mathrm{SO}_{2}\right)$, hydrogen sulfide $\left(\mathrm{H}_{2} \mathrm{~S}\right)$, methane $\left(\mathrm{CH}_{4}\right)$ and total hydrocarbons (THC).

Results indicated a slight increase of concentration level over the years, where a noticeable increase of $\mathrm{SO}_{2}$ and $\mathrm{H}_{2} \mathrm{~S}$ concentrations for the period 2010-2013 was identified. In all cases however, the concentrations were below the limits set by the National legislation and alarm values. In general, few episodes (especially during September) characterize the air quality in the examined area. High average to median ratios especially for years 2014 and 2015 indicate episodes of high level concentrations of $\mathrm{SO}_{2}$ and $\mathrm{H}_{2} \mathrm{~S}$ whereas THC and $\mathrm{CH}_{4}$ did not exhibit similar behavior, suggesting that sulfur and hydrocarbon pollutants may exhibit different characteristics (e.g. sources, sinks, seasonality).
Concentration levels measured during warm/cold period and weekdays/weekends were identical for hydrocarbons indicating uniform sources. On the other hand, regarding sulfur containing pollutants, $\mathrm{SO}_{2}$ concentrations were slightly higher during the cold period, whereas $\mathrm{H}_{2} \mathrm{~S}$ concentrations were higher during summer. The correlation of $\mathrm{SO}_{2} / \mathrm{H}_{2} \mathrm{~S}$ and $\mathrm{THC} / \mathrm{CH}_{4}$ is an indication that the specific pairs of pollutants originate from common sources.

In spite of the aggravating factors that characterize the examined area, it can be inferred that the air quality in terms of the four pollutants under examination is satisfying and does not pose at the moment any danger to human health. A more detailed analysis is necessary though (incl. source apportionment, more sampling spots, etc.) to extract safer results. The authors plan to undertake the specific research in the future.

\section{Acknowledgement}

The authors would like to thank Kavala Oil S.A. for providing the data that were utilized to conduct the specific study.

This is an Open Access article distributed under the terms of the Creative Commons Attribution License

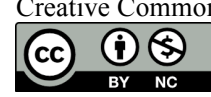

\section{References}

[1] Mirasgedis, S.; Hontou, V.; Georgopoulou, E.; Sarafidis, Y.; Gakis, N.; Lalas, D.P.; Loukatos, A.; Gargoulas, N.; Mentzis, A.; Economidis, D.; Triantafilopoulos, T.; Korizi, K.; Mavrotas, G. Environmental damage costs from airborne pollution of industrial activities in the greater Athens, Greece area and the resulting benefits from the introduction of BAT. Environ. Impact Assess. Rev. 2008, 28, 39-56.

[2] Simpson, I.J.; Marrero, J.E.; Batterman, S.; Meinardi, S.; Barletta, B.; Blake, D.R. Air quality in the industrial heartland of Alberta, Canada and potential impacts on human health. Atmos. Environ. 2013, 81, 702-709.

[3] Odabasi, M.; Tolunay, D.; Kara, M.; Falay, E.O.; Tuna, G.; Altiok, H.; Dumanoglou, Y.; Bayram, A.; Elbir, T. Investigation of spatial and historical variations of air pollution around an industrial region using trace macro elements in tree components. Sci. Total Environ. 2016, 550, 1010-1021.

[4] Gong, J.; Hu, Y.; Liu, M.; Bu, R.; Chang, Y.; Li, C.; Wu, W. Characterization of air pollution index and its affecting factors in industrial urban areas in Northeastern China. Pol. J. Environ. Stud. 2015, 24 (4), 1579-1592.

[5] Baawain, M.S.; Al-Serihi, A.S. Systematic approach for the prediction of ground-level air pollution (around an industrial port) using an artificial neural network. Aerosol Air Qual. Res. 2014, 14, 124-134.

[6] Guerreiro, C.B.B.; Foltescu, V.; Leeuw, F. Air quality status and trends in Europe. Atmos. Environ. 2014, 98, 376-384.

[7] EEA. Air quality in Europe, European Environment Agency, EEA Report No 28/2016, ISSN 1977-8449, doi: 10.2800/80982.
[8] Peel, M.C.; Finlayson, B.L.; McMahon, T.A. Updated world map of the Köppen-Geiger climate classification. Hydrology and Earth System Sciences. 2007, 11, 1633-1644

[9] U.S. EPA. Sulfur Dioxide Pollution, United States Environmental Protection Agency, https://www.epa.gov/so2-pollution (accessed Aug 2017).

[10] ATSDR. Toxicological profile for hydrogen sulfide and carbonyl sulfide, Agency for Toxic Substances and Disease Registry, U.S. Department of Health and Human Services, (November 2016).

[11] Wang, L.; Guan, Q.; Wang, F.; Yang, L.; Liu, Z. Association between heating seasons and criy=teria air pollutants in three provincial capitals in northern China: Spatiotemporal variation and sources contribution. Building and Environment. 2018, 132, 233244.

[12] Alizadeh-Choobari, O.; Bidokhti, A.A.; Ghafarian, P.; Najafi, M.S. Temporal and spatial variations of particulate matter and gaseous pollutants in the urban area of Tehran. Atmospheric Environment. 2016, 141, 443-453.

[13] Sarigiannis, D.A.; Handakas, E.J.; Kermenidou, M.; Zarkadas, I.; Gotti, A.; Charisiadis, P.; Makris, K.; Manousakas, M.; Eleftheriadis, K.; Karakitsios, S.P. Monitoring of air pollution levels related to Charilaos Trikoupis Bridge. Science of the Total Environment, 2017, 609, 1451-1463.

[14] Squizzato, S.; Masiol, M.; Rich, D.Q.; Hopke, P.K. PM2.5and gaseous pollutants in New York State during 2005-2016: Spatial variability, temporal trends, and economic influences. Atmospheric Environment, 2018, 183, 209-224. 